\title{
AKTIVITAS BELAJAR SISWA YANG MENGINDIKASIKAN SISWA BERPIKIR KRITIS PADA PEMBELAJARAN BIOLOGI DI KELAS XI IPA-7 MAN 1 MEDAN
}

\section{STUDENT LEARNING ACTIVITIES WHICH INDICATE STUDENT CRITICAL THINKING TO LEARNING BIOLOGY IN XI IPA-7 CLASS MAN 1 MEDAN}

\author{
Nurlaizar Andriani ${ }^{*}$ dan Zulkifli Simatupang \\ Program Studi Pendidikan Biologi, FMIPA, Universitas Negeri Medan, Medan \\ Jl. Willem Iskandar Psr. V Medan Estate, Medan, Indonesia, 20221 \\ ${ }^{*}$ E-mail : nurlaizar24@gmail.com
}

\begin{abstract}
ABSTRAK
Penelitian ini bertujuan untuk melihat aktivitas belajar siswa yang mengindikasikan siswa berpikir kritis pada pembelajaran biologi kelas XI IPA-7 MAN 1 Medan Tahun Pembelajaran 2015/2016. Populasinya yaitu siswa kelas XI IPA-7 MAN 1 Medan Tahun Pembelajaran 2015/2016 berjumlah 40 orang. Sampel ditentukan dengan Random Sampling, dimana sampel berjumlah 20 orang. Jenis penelitian yang digunakan dalam penelitian ini merupakan penelitian deskriptif, dengan menggunakan lembar aktivitas belajar siswa sebagai alat pengumpul data penelitian. Pengamatan dilakukan sebanyak 2 kali pertemuan. Dari hasil data yang diperoleh diketahui bahwa kemunculan aktivitas berpikir kritis sangat rendah dimana aktivitas belajar yang muncul hanyalah aktivitas menjawab pertanyaan. Pada pengamatan pertama aktivitas berpikir kritis diperoleh dengan persentase sebesar 11,11\% dan untuk pengamatan kedua aktivitas berpikir kritis diperoleh dengan persentase sebesar $16,6 \%$. Ada beberapa faktor yang melatar belakangi rendahnya kemunculan aktivitas berpikir kritis ini yaitu disebabkan oleh pertanyaan yang muncul belum mampu mendorong munculnya aktivitas-aktivitas berpikir kritis dan strategi pembelajaran yang digunakan oleh guru yaitu strategi pembelajaran ekspositori yangmana strategi pembelajaran ini memang tidak didesain untuk memunculkan aktivitas belajar yang lain.

Kata kunci : Aktivitas Belajar, Berpikir Kritis
\end{abstract}

\begin{abstract}
This research aims to determine students 'learning activities that indicate students' critical thinking in biology class XI IPA-7 class MAN 1 Medan Academic Year 2015/2016. The population of this research is 40 students of XI IPA-7 class MAN 1 Medan Academic Year 2015/2016. The samples is determined by random sampling, where samples numbered 20 students. This type of research used in this research is a descriptive research, using student activity sheets as research instrument. Observations were made as much as 2 times. From the survey results known that the occurrence of activity critical thinking is very low, where learning activities that appear only answered questions activity. In the first observation of critical thinking activity obtained with a percentage of $11.11 \%$ and for the second observation critical thinking activity obtained with a percentage of $16.6 \%$. There are several background factors lack critical thinking is the emergence of activity that is caused by the questions raised have not been able to encourage the emergence of critical thinking activities and learning strategies used by teachers, learning strategies expository learning strategies to which it is indeed not designed for show activity learning.

Kata kunci : Learning Activities, Critical Thinking
\end{abstract}

\section{PENDAHULUAN}

Berdasarkan hasil wawancara dengan guru biologi, kenyataan yang ditemui pada siswa kelas XI IPA-7 Madrasah Aliyah Negeri 1 Medan tahun Pelajaran 2015/2016, menjelaskan bahwa dalam mempelajari Biologi mereka masih terlalu teoritis dan kurang mengembangkan kemampuan berpikir kritis. Dimana siswa masih kesulitan menjawab pertanyaan yang diberikan oleh guru dan siswa 
belum menunjukkan pengembangan yang sesuai dengan potensi serta kemampuan mereka. Selain itu, terdapat beberapa siswa yang masih sulit dalam belajar kelompok, berkomunikasi, memecahkan masalah ketika diajukan contoh suatu permasalahan yang nyata, serta belum bisa mengambil keputusan sebagai solusi yang tepat dari suatu permasalahan.

Keadaan ini mengindikasikan bahwa selama ini siswa terbiasa belajar hanya dengan mendengarkan informasi yang disampaikan oleh guru saja tanpa mereka tahu kondisi yang sebenarnya terjadi dalam kehidupan seharihari. Ini sesuai dengan pendapat Noviyanti (2015) dalam artikel ilmiahnya bahwa Metodemetode seperti ini diduga kurang memfasilitasi siswa untuk mengembangkan kemampuan berpikir kritisnya, sebab siswa hanya diam mendengarkan penjelasan guru, diskusi tidak efektif karena hanya bersifat informatif saja, latihan soal tidak optimal karena siswa hanya mengerjakan soal-soal latihan yang terdapat dalam buku yang tersedia di perpustakaan sekolah dengan cara memindahkan jawaban yang sudah tersedia di buku tersebut, sedangkan praktikum umumnya bersifat pengujian teoritis dasar saja, sehingga mengakibatkan keterampilan proses sains dan kemampuan berfikir kritisnya kurang tergali.

Sementara itu dari hasil wawancara yang dilakukan dengan siswa/siswi kelas XI IPA7 Madrasah Aliyah Negeri 1 Medan Tahun Pelajaran 2015/2016, ditemukan fakta bahwa siswa sangat mengalami kesulitan menjawab pertanyaan yang diberikan oleh guru, dimana guru bertanya mengenai perihal yang berkaitan dengan mengidentifikasi suatu masalah, selain itu siswa mengaku bahwa pertanyaan yang diberikan guru sangat sulit, sehingga murid mengalami kesulitan untuk menjawab pertanyaan. Kesulitan ini diduga karena pertanyaan yang diajukan guru membutuhkan jawaban analisis dan argumentasi menggunakan berbagai pengetahuan yang dimiliki siswa yang mengarah pada kemampuan berpikir kritis siswa.

Hal ini sesuai dengan yang diungkapkan Murti (2013) dalam blok ilmiahnya bahwa berpikir kritis mencakup keterampilan menafsirkan dan menilai pengamatan, informasi, argumentasi, dan penggunaan alasan yang logis.

Di samping itu, siswa merasa kebingungan terhadap materi yang diajarkan oleh guru, sebab guru terlalu fokus berceramah sehingga mengakibatkan murid mengalami kesulitan untuk tetap fokus mendengarkan, murid juga mengaku bosan ketika semua materi diberikan hanya dengan ceramah saja. Dari sini dapat diketahui bahwa, metode pembelajaran yang digunakan tidak sesuai dengan tujuan pembelajaran sehingga mengakibatkan murid sulit untuk berpikir kritis.

Hasruddin (2009) menjelaskan bahwa siswa hari ini, sebagai pemimpin atau ilmuwan di masa depan perlu dipersiapkan dengan membiasakan mereka melakukan kebiasaan berpikir kritis. Mereka perlu dipersiapkan dalam menghadapi tantangan dan persoalan yang semakin kompleks di masa depan. Masalah-masalah akan menjadi sangat banyak dan sangat rumit, oleh sebab itu pembelajaran semestinya memberikan kesempatan kepada pelajar untuk berpikir kritis agar mereka tumbuh dan berkembang dan mampu menghadapi berbagai tantangan.

Akan tetapi untuk melihat aktivitasaktivitas belajar yang mengindikasikan siswa berpikir kritis ini tidak dapat dilihat ataupun dimunculkan pada semua materi pelajaran biologi sebab jika dilihat dari segi materi pelajaran ada beberapa materi pelajaran yang sangat berpotensi untuk memunculkan aktivitas berpikir kritis seperti halnya pada materi: 1) Ruang lingkup biologi, manfaat, dan bahayanya; 2) Keanekaragaman hayati; 3) Ekosistem; 4) Sistem Reproduksi manusia dan lain sebagainya. Hal ini dikarenakan strategi pembelajaran yang digunakan oleh guru dapat berupa strategi pembelajaran yang cenderung 
berbasis masalah yangmana strategi pembelajaran tersebut memang bertujuan untuk memunculkan aktivitas-aktiviatas yang mengindikasikan siswa berpikir kritis. Namun ada beberapa materi pelajaran yang kurang sesuai ataupun kurang tepat jika digunkan untuk melihat aktivitas-aktivitas belajar yang mengindikasikan siswa berpikir kritis ini, seperti halnya: 1) Kingdom protista; 2) Kingdom fungi; 3) Kingdom plantae; 4) Enzim; 5) Metbolisme dan lain sebagainya. Karena pada umumnya materi ajar ini cenderung lebih mengarahkan siswa pada mengingat dan menghafal sehingga aktivitas-aktivitas lain yang diharapkan seperti aktivitas bertanya, aktivitas menjawab pertanyaan, aktivitas argumentasi, aktivitas mengkomunikasikan, dan aktivitas menyimpulkan akan sangat sulit untuk ditemukan pada saat pembelajaran biologi dengan materi-materi pelajaran tersebut. Dan sejauh ini kemampuan berpikir kritis hanya dapat dilihat maupun diukur menggunakan serangkaian tes yang dikembangkan melalui indikator-indikator berpikir kritis.

Mencermati latar belakang di muka, perlu dilakukan penelitian mengenai bentukbentuk aktivitas belajar siswa yang muncul selama pembelajaran biologi, dimana aktivitas belajar tersebut mengindikasikan siswa berpikir kritis.

\section{METODE PENELITIAN}

Penelitian ini dilaksanakan di Madrasah Aliyah Negeri (MAN) 1 Medan yang beralamat JIn. Willem Iskandar No.7B Medan Kode Pos: 20222. Penelitian ini dilaksanakan pada bulan Mei sampai Juli 2016. Populasi dalam penelitian ini adalah seluruh siswa yang ada di satu kelas XI IPA-7 Madrasah Aliyah Negeri 1 Medan Tahun Pembelajaran 2015/2016 yang terdiri dari 40 siswa.

Sampel penelitian ditetapkan $50 \%$ dari total populasi untuk meyakinkan keabsahan data, dimana $50 \%$ dari total populasi yaitu sebanyak 20 orang antara lain siswa (S1; S2; S3;...; S20) dan bagi siswa yang tidak masuk ke dalam sampel di beri kode (S). Pemilihan sampel tersebut dengan cara random (acak) dan menggunakan teknik sampling acak sederhana (simple random sampling). Arikunto (2003) mengungkapkan bahwa sampling acak sederhana (simple random sampling) yaitu apabila peneliti mengambil sampel dengan melakukan lotre terhadap semua populasi. Semua objek yang termasuk dalam populasi mempunyai hak untuk dijadikan anggota sampel. Masing-masing subjek diberi nomor urut sesuai dengan abjad nama atau nomor semula. Dengan kertas gulungan yang yang berisi nomor-nomor subjek, dilakukan lotre seperti cara lotre yang sudah umum dikenal.

Penelitian yang digunakan dalam penelitian ini adalah penelitian Deskriptif, Penelitian ini secara spesifik lebih diarahkan pada penggunaan teknik survei. Teknik survei ini merupakan suatu teknik penelitian yang berupaya untuk menjelaskan kondisi apa yang ada saat ini (Arikunto, 2013).

Pada dasarnya penelitian deskriptif dengan teknik survei bertujuan untuk menjelaskan dan menggambarkan suatu kondisi secara apa adanya. Maka dalam penelitian ini, peneliti akan menggunakan teknik survei untuk mengungkap tentang aktivitas belajar siswa yang mengindikasikan siswa berpikir kritis dalam pembelajaran biologi di kelas XI IPA-7 MAN 1 Medan.

Prosedur penelitian merupakan tahaptahap kegiatan yang dilakukan peneliti dalam proses penelitian sesuai dengan tujuan yang ingin dicapai (Arikunto, 2006). Adapun langkahlangkah yang dilakukan dalam penelitian ini adalah sebagai berikut: 1) Tahap Persiapan Pada tahap ini, hal-hal yang dilakukan adalah: Mensurvei tempat penelitian di MAN 1 Medan, Membuat Proposal Penelitian, Seminar Proposal Penelitian, Memvalidasi lembar observasi aktivitas belajar siswa kepada validator ahli, Mengurus surat izin penelitian ke fakultas MIPA dan Jurusan Biologi; 2) Tahap Pelaksanaan: Melakukan simulasi pengamatan aktivitas belajar siswa di kelas XI IPA-7 MAN 1 
Medan, Melaksanakan penelitian pada siswa kelas XI IPA-7 MAN 1 Medan; 3) Tahap Pengumpulan Data, Data dalam penelitian ini diperoleh dari catatan lapangan, lembar observasi siswa kelas XI IPA-7 MAN 1 Medan, antara lain: Mencatat kondisi yang ada pada pembelajaran biologi yang berlangsung, dalam bentuk catatan lapangan, Melakukan simulasi pengisian lembar observasi dengan observer, hal ini dilakukan untuk menyamakan persepsi, Mengisi lembar observasi aktivitas belajar siswa sesuai dengan pengamatan yang dilakukan dii lapangan, dengan jumlah observer 2 orang dengan waktu 2 x 90 menit; 4) Tahap Pengolahan Data. Pada tahap ini, hal-hal yang dilakukan adalah: Merapikan catatan lapangan tentang kondisi dan aktivitas belajar siswa yang muncul pada pembelajaran biologi, Menyusun data aktivitas siswa belajar siswa yang muncul, yang mengindikasikan siswa berpikir kritis berdasarkan pada lembar observasi aktivitas belajar siswa, Menganalisis data aktivitas belajar yang muncul dengan menggunakan teknik analisis data deskriptif.

Untuk memperoleh data yang diperlukan dalam penelitian maka digunakan instrumen pengumpul data, yaitu sebagai berikut : 1) Catatan Lapangan (Field note), seluruh kegiatan atau aktivitas yang terjadi selama proses pembelajaran yang berlangsung akan dijelaskan kembali dalam catatan lapangan; 2) Lembar observasi aktivitas belajar siswa, pengamatan dilakukan selama proses pembelajaran berlangsung, pengamatan dilakukan oleh peneliti dan satu orang observer dengan menggunakan lembar observasi. Observasi dilakukan pada saat pembelajaran biologi berlangsung yakni selama 90 menit atau dua jam pelajaran dengan intensitas pengamatan sebanyak 2 kali terhadap aktivitas belajar siswa yang dapat terlihat.

Adapun beberapa teknik analisis data yaitu sebagai berikut: 1) Melihat kembali kondisi pembelajaran biologi yang berlangsung dan aktivitas apa saja yang muncul selama proses pembelajaran biologi di kelas XI IPA-7 yang telah tercatat dalam catatan lapangan. Sampel yang telah didapat secara random sebanyak 20 orang kemudian diamati aktivitas belajarnya pada saat pembelajaran biologi berlangsung dengan menggunakan lembar observasi aktivitas belajar siswa; 2) Dalam penelitian ini data yang diperoleh adalah data tentang aktivitas belajar siswa yang mengindikasikan siswa berpikir kritis selama pembelajaran biologi berlangsung; 3) Menganalisis aktivitas belajar siswa yang mengindikasikan siswa berpikir kritis yang muncul selama proses pembelajaran biologi; 4) Data diolah dan dianalisis menggunakan rumus deskriptif presentase, yaitu untuk mengetahui seberapa banyak aktivitas belajar siswa yang muncul, dimana aktivitas tersebut mengindikasikan siswa berpikir kritis pada pembelajaran biologi yang dinyatakan dalam bentuk seberapa banyak sikap tersebut muncul, kemudian data tersebut dibuat dalam bentuk persentase dengan menggunakan perhitungan presentase sebagai berikut: a. Teknik analisis data untuk Aktivitas Berpikir Kritis :

$\frac{\text { EAktivitas yang Muncul }}{\sum \text { Jumlah pengamatan }} \times 100 \%$

b.Teknik analisis data untuk keseluruhan presentase siswa yang berpikir kritis maka digunakanlah rumus sebagai berikut:

Eskor dicapai seluruh siswa

: $\frac{\text { Skor Maximal seluruh siswa }}{\text { Sk }} \times 100 \%$

\section{HASIL PENELITIAN}

Data Aktivitas Pengamatan Pertama

Pada hari Rabu, tanggal 4 Mei 2016, pukul. 09.35-11.05. dilakukan proses belajar biologi di kelas XI IPA-7 dimana saya dan 2 orang teman saya sebagai observer yang mengamati kegiatan pembelajaran. Kegiatan awal guru membuka pembelajaran dengan mengucapkan salam dan menyapa anak-anak. Kemudian guru bertanya mengenai topik pembelajaran semalam. Selama proses pembelajaran terjadi, terdapat beberapakali kegiatan tanya jawab yang dilakukan oleh guru dan siswa. Dimana bagi siswa yang dapat 
menjawab pertanyaan akan menulis jawaban pada papan tulis dan jawaban tersebut tidak di ungkapkan secara verbal. Akan tetapi ditunjuk siswa lain untuk membaca jawaban tersebut sambil menilai apakah jawaban tersebut benar atau salah.

\section{Refleksi}

Pada penelitian ini terlihat guru menggunakan strategi pembelajaran ekspositori, dimana strategi pembelajaran ekspositori ini memadukan metode ceramah, tanya jawab. Pada pengamatan ini dapat diketahui bahwa aktivatas berpikir kritis seperti aktivitas argumentasi, aktivitas menyimpulkan pembelajaran, dan aktivitas mengkomunikasikan tidak muncul dalam pengamatan pertama hal ini dikarenakan aktivitas berpikir kritis tersebut memang tidak didesain untuk muncul selama proses pembelajaran berlangsung.

kegiatan awal membuka pembelajaran yang di lakukan oleh guru cukup baik sehingga membuat siswa terfokus pada guru, akan tetapi siswa masih merasa ketakutan untuk maju ke depan tiap kali di arahkan guru untuk menulis jawaban dipapan tulis, saat proses tanya jawab kelas sangat ribut. Akan tetapi siswa-siswa tampak semangat membaca karena merasa takut jika dipilih untuk menuliskan jawaban di papan tulis. adapun serangkaian pertanyaan yang diajukan oleh guru selama proses belajar mengajar dalam pertemuan pertama belum mendorong kemunculan aktivitas berpikir kritis.

Dengan demikian, dapat diketahui bahwa aktivitas belajar siswa yang muncul pada pengamatan pertama hanyalah aktivitas menjawab pertanyaan dengan presentase $11,11 \%$ dari 20 orang siswa yang menjadi sampel. Pada pengamatan pertama ini dapat diketahui bahwa siswa yang melakukan aktivitas belajar siswa yang mengindikasikan siswa berpikir kritis adalah sebanyak 2 orang dari 20 orang siswa yang menjadi sampel, yaitu dengan presentase $10 \%$.

\section{Pengamatan Kedua}

Pada hari Selasa, tanggal 10 Mei 2016, pukul. 10.20-11.50. dilakukan proses belajar biologi di kelas XI IPA-7 dimana saya dan 2 orang teman saya sebagai observer yang mengamati kegiatan pembelajaran. Kegiatan awal guru membuka pembelajaran dengan mengucapkan salam dan menyapa anak-anak. Kemudian guru bertanya mengenai buku kendali yang telah ditugaskan minggu lalu.

Guru mempersilahkan siswa untuk membaca buku selama 10 menit. Kemudian guru mulai mengemukakan pertanyaan tentang proses atau fase yang terjadi pada saat menstruasi. Hanya seorang siswa saja yang berani maju menghadap guru di depan mejanya tanpa membawa buku, yaitu S3. Setelah S3 duduk ke bangkung S12 mengangkat tangannya dan maju ke depan menghadap guru tanpa membawa buku. Siswa-siswa lain luput dari perhatian guru sibuk bertanya dan sibuk menghafal. Suasana kelas mulai ribut. Setelah itu guru kembali bertanya "siapa lagi yang mau maju ke depan?" semua siswa tampak tak acuh sambil sibuk menghafal jawaban mereka masing-masing. Karena terlihat tak ada lagi siswa yang berani maju ke depan menjawab pertanyaan. Ibu guru mulai menjelaskan jawaban dari pertanyaan yang diajukannya.

\section{Refleksi}

Selama proses pembelajaran berlangsung guru menggunakan strategi pembelajaran yang sama seperti pada pertemuan pertama yaitu strategi pembelajaran ekspositori, dimana strategi pembelajaran ekspositori ini memadukan metode ceramah, dan metode tanya jawab. Pada pengamatan ini dapat diketahui bahwa aktivatas berpikir kritis seperti aktivitas argumentasi, aktivitas menyimpulkan pembelajaran, dan aktivitas mengkomunikasikan tidak muncul dalam pengamatan pertama hal 
ini dikarenakan aktivitas berpikir kritis tersebut memang tidak didesain untuk muncul selama proses pembelajaran berlangsung.

Dalam pengamatan kedua ini tampak banyak sekali siswa yang sibuk sendiri ada yang sibuk menghafal, tapi ada juga yang acuh tak acuh, ada juga yang sibuk bertanya. Akan tetapi ada hal yang menarik disini bahwa S3, siswi yang pertama sekali maju ke depan untuk menjawab pertanyaan yang di ajukan oleh ibu guru ternyata mampu menjelaskan kembali kepada beberapa temannya, tiap kali temannya bertanya ia berusaha menjelaskannya secara berulang-ulang kemudian ia kembali bertanya terhada temannya "udah ngerti" jika temannya menjawab "belum" S3 akan kembali menjelaskannya. Sayangnya aktivitas mengkomunikasikan yang dilakukan oleh S3 ini masih luput dari perhatian guru.

Adapun pertanyaan yang muncul dalam proses pembelajaran ketika Pengamatan Berlangsung adalah sebagai berikut: "Sebutkan dan jelaskan proses-proses yang terjadi selama menstruasi?" akan tetapi pertanyaan ini belum tergolong dalam pertanyaan yang memicu aktivitas berpikir kritis.

Dengan demikian dapat diketahui bahwa aktivitas belajar siswa yang muncul pada pengamatan kedua hanyalah aktivitas menjawab pertanyaan dengan presentase $16,6 \%$ dari 20 orang siswa yang menjadi sampel. Pada pengamatan pertama ini dapat diketahui bahwa siswa yang melakukan aktivitas belajar siswa yang mengindikasikan siswa berpikir kritis adalah sebanyak 2 orang dari 20 orang siswa yang menjadi sampel, yaitu dengan presentase $10 \%$.

\section{PEMBAHASAN}

Berdasarkan analisis terhadap data hasil penelitian diperoleh petunjuk bahwa kemunculan aktivitas belajar siswa yang diamati sangatlah rendah bahkan beberapa aktivitas pembelajaran tidak muncul sama sekali, hal ini dikarenakan siswa belum diarahkan untuk melakukan aktivitas tersebut.
Hal ini dapat diketahui karena aktivitas yang muncul hanyalah aktivitas yang didesain oleh guru saja. Akan tetapi aktivitas yang tidak didesain tidak muncul sama sekali dengan kata lain aktivitas belajar anak sangat bergantung pada pembelajaran yang telah didesain oleh guru mata pelajaran.

Dalam penelitian ini, yaitu sebanyak dua kali pengamatan guru tampak menggunakan strategi pembelajaran ekspositori dimana strategi pembelajaran ini memadukan metode ceramah dan tanya jawab. Sehingga ketika strategi ini diterapkan dalam pembelajaran biologi maka aktivitas yang diharapkan seperti aktivitas argumentasi, aktivitas menyimpulkan pembelajaran, dan aktivitas mengkomunikasikan tidak muncul sebab aktivitas ini memang tidak di desain dalam strategi pembelajaran ekspositori. Sehingga selama proses pembelajaran berlangsung aktivitas yang muncul hanyalah aktivitas menjawab pertanyaan saja sebab aktivitas tersebutlah yang didesain dalam strategi pembelajaran ekspositori.

Sebenarnya strategi pembelajaran ekspositori ini sangat efektif jika materi pelajaran yang harus dikuasai siswa cukup luas, sementara itu waktu yang dimiliki untuk belajar terbatas, dan strategi ini sangat cocok digunakan untuk jumlah siswa dan ukuran kelas yang besar, selain itu guru bisa mengontrol urutan dan keluasan materi pembelajaran, mengetahui sampai sejauh mana siswa menguasai bahan pelajaran yang disampaikan.

\section{Hasil Penelitian Pengamatan Pertama}

Intensitas siswa melakukan aktivitas menjawab pertanyaan pada pengamatan pertama memiliki presentase sebesar $10 \%$ dan Sementara aktivitas belajar yang mengindikasikan siswa berpikir kritis lainnya tidak muncul. Dapat dilihat dalam catatan lapangan bahwa aktivitas belajar yang muncul adalah aktivitas yang mendorong siswa untuk menjawab pertanyaan saja sehingga aktivitas lain yang tidak didesain tidak muncul sama 
sekali. Hal ini disebabkan karena pada pengamatan pertama guru tampak menggunakan strategi pembelajaran ekspositori yang hanya memadukan antar metode ceramah dengan metode tanya jawab, jelas saja aktivitas berpikir kritis yang lain tidak muncul dalam pengamatan ini karena memang aktivitas tersebut tidak didesain untuk muncul.

Hal lain yang menjadi penyebab rendahnya aktivitas belajar yang mengindikasikan siswa berpikir kritis adalah pertanyaan yang muncul selama proses pembelajaran belum mampu mendorong aktivitas berpikir kritis. Seperti yang telah dipaparkan dalam data pada pertemuan pertama dapat dilihat bahwa dari 7 pertanyaan yang diajukan hanya 2 pertanyaan yang mampu mendorong aktivitas berpikir kritis. Peratnyaan yang mendorong aktivitas berpikir kritis ini sangat erat kaitannya dengan motivasi belajar, dimana motivasi memiliki pengaruh terhadap perilaku belajar siswa, yaitu motivasi mendorong meningkatnya semangat dan ketekunan dalam belajar. Motivasi belajar memegang peranan yang penting dalam memberi gairah, semangat belajar, selain itu motivasi ini merupakan daya penggerak dalam diri seseorang untuk melakukan aktivitasaktivitas guna mencapai tujuan tertentu. Dari sini dapat diketahui bahwa pertanyaan yang mampu memicu kemunculkan aktivitas berpikir kritis ini akan memotivasi siswa sehingga dapat memunculkan aktivtas-aktivitas yang mengindikasikan siswa berpikir kritis.

\section{Hasil Penelitian Pengamatan Kedua}

Sama halnya seperti pada pengamatan pertama, pada pengamata kedua ini guru tampak menggunakan strategi pembelajaran ekspositori yang hanya memadukan antara metode ceramah dengan metode tanya jawab, hal ini menjadi salah satu faktor penyebab aktivitas berpikir kritis seperti aktivitas argumentasi, aktivitas menyimpulkan pembelajaran, dan aktivitas mengkomunikasikan tidak muncul.
Pada pengamatan kedua ini intensitas siswa melakukan aktivitas menjawab pertanyaan memiliki presentase sebesar $10 \%$. Dapat diketahui bahwa aktivitas yang mengindikasikan siswa berpikir kritis yang lainnya tidak muncul sama sekali, sama halnya dengan pengamatan sebelumnya bahwa aktivitas belajar yang muncul hanyalah aktivitas yang didesain oleh guru saja. Selain itu pada pengamatan kedua siswa tampak sangat pasif terlihat ada yang saling diskusi, tiduran, bahkan mengobrol, namun ada juga siswa yang sibuk menghafal agar dapat maju kedepan kelas untuk menjawab pertanyaan. Siswa yang tidak bersemangat dalam belajarnya, akan terlihat dari aktifitas ia dalam belajar, ia terlihat malasmalasan, sering ngobrol dengan temannya, perhatian tidak fokus ke pelajaran, membuka buku tapi bukan buku yang sedang dipelajari, tidur di kelas, sibuk sendiri dengan HP-nya, atau bahkan siswa tersebut pandangannya kosong.

Sehingga untuk meningkatkan aktivitas berpikir kritis siswa ini, pembelajaran perlu didesain untuk memunculkan aktivitas berpikir kritis yang diharapkan yaitu dengan memberiakan strategi ataupun metode pembelajaran yang sesuai yaitu metode pembelajaran yang dapat memunculkan aktivitas-aktivitas belajar yang mengindikasikan siswa berpikir kritis, selain itu perlu adanya pertanyaan yang mampu mendorong aktivitas berpikir kritis siswa yaitu dengan memberi pertanyaan alternatif seperti yang terdapat pada bab 2 di depan.

Adapun model pembelajaran yang sesuai untuk memunculakan aktivitas berpikir kritis yang lain seperti aktivitas argumentasi, aktivitas menyimpulkan pembelajaran, dan aktivitas mengkomunikasikan yang tidak muncul dalam pengamatan yaitu dengan menggunakan model Pembelajaran Cooperative Script. Hal ini karena model Pembelajaran Cooperative Script merupakan model pembelajaran yang penyampaian materi ajarnya diawali dengan pemberian wacana atau 
ringkasan materi ajar siswa yang kemudian diberikan kesempatan kepada siswa untuk membacanya sejenak dan memberikan/memasukkan ide-ide atau gagasan-gagasan baru kedalam materi ajar yang diberikan guru, lalu siswa diarahkan untuk menunjukkan ide-ide pokok yang kurang lengkap dalam meteri yang ada secara bergantian sesama pasangan masing-masing. Dengan model pembelajaran Cooperative Script, siswa akan terlatih mengembangkan ideidenya sehingga siswa dapat mengkonstruksi sendiri pengetahuan. Disamping itu model ini juga akan merangsang aktivitas belajar siswa karena dalam model pembelajaran Cooperative Script, setiap siswa terlibat dalam dalam proses pembelajaran dengan peran dan tugasnya masing-masing.

\section{KESIMPULAN}

Berdasarkan hasil penelitian yang telah diuraikan pada Bab IV, maka kesimpulan dalam penelitian ini adalah sebagai berikut: 1) Terdapat satu aktivitas berfikir kritis yang muncul, yaitu aktivitas menjawab pertanyaan; 2) Aktivitas berpikir kritis yang dominan muncul adalah aktivitas menjawab pertanyaan, dimana aktivitas ini muncul sebanyak 5 kali dalam 2 kali pengamatan; 3) Intensitas kemunculan aktivitas berpikir kritis hanya tampak pada aktivitas menjawab pertanyaan. Dimana aktivitas menjawab pertanyaan ini pada pertemuan pertama memiliki presentase sebesar $11,11 \%$ dan pada pengamatan kedua memiliki presentase sebesar $16,6 \%$.

\section{UCAPAN TERIMA KASIH}

Ucapan terima kasih penulis ucapkan kepada Bapak Kepala Sekolah MAN 1 Medan, kepada Bapak/lbu guru Biologi yang telah membantu serta seluruh siswa di MAN 1 Medan.

\section{DAFTAR PUSTAKA}

Arikunto, S., (2000), Manajemen Penelitian. Penerbit Rineka Cipta, Jakarta.
Hasruddin., (2009), Memaksimalkan Kemampuan Berpikir Kritis Melalui Pendekatan Kontekstual, Jurnal Tabularasa Pps Unimed, 6 (1):48-60.

Murti, B., (2013), Berpikir Kritis (Critical Thinking), seri kuliah Blok Budaya Ilmiah, fakultas kedokteran, Universitas Sebelas Maret, Surakarta.

Noviyanti, R., (2015), Pengaruh Pendekatan Keterampilan Proses Sains Terhadap Berpikir Kritis Siswa Pada Materi Ekosistem, Artikel, FMIPA, Universitas Lampung, Lampung. 